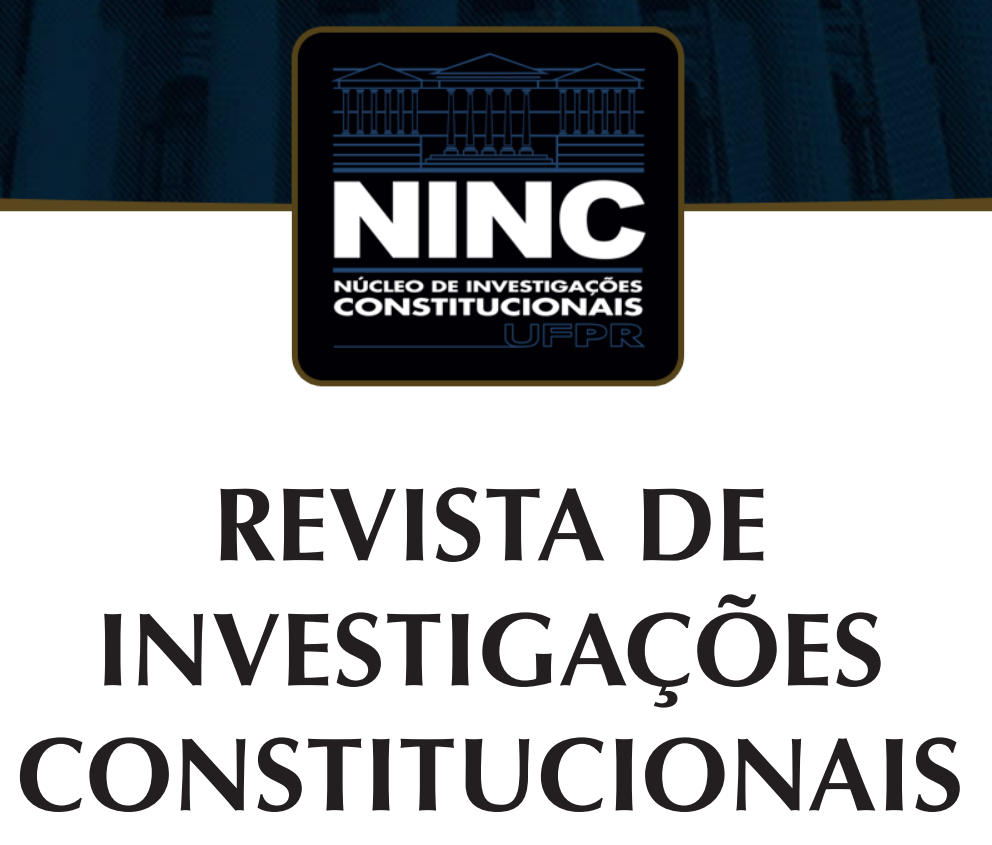

JOURNAL OF CONSTITUTIONAL RESEARCH

vol. 5 | n. 3 | setembro/dezembro 2018 | ISSN 2359-5639 | Periodicidade quadrimestral Curitiba | Núcleo de Investigações Constitucionais da UFPR | www.ninc.com.br 


\title{
The Brazilian Constitution of 1988: a comparative appraisal
}

\section{A Constituição Brasileira de 1988: uma avaliação comparativa}

\author{
ARTURO ALVARADO* \\ El Colegio de México (México) \\ http://orcid.org/0000-0002-6922-3507 \\ alvarado@colmex.mx
}

Recebido/Received: 12.08 .2018 / August $12^{\text {th }}, 2018$ Aprovado/Approved: 01.09.2018 / September 1 15t, 2018

\section{Abstract}

This article examines the 1988 constitution of The Federative Republic of Brazil and its significance after 30 years of its implementation. Asserts some of its more advance social, political features and evaluates the current challenges to implement a democratic governance, based on a Rule of Law within the evolving constitutional framework. It also makes some comparisons between the Brazilian constitutional and political processes and other Latin American experiences, weighing whether or not Brazil started a new era of constitutional thinking in Latin America.

Keywords: Constitution; Rule of Law; justice; democratic governance; liberal constitutionalism.

\section{Resumo}

Este artigo examina a Constituição de 1988 da República Federativa do Brasil e seu significado após 30 anos de implementação. Afirma algumas de suas características sociais e políticas mais avançadas e avalia os desafios atuais para implementar uma governança democrática, baseada em um Estado de Direito dentro da estrutura constitucional em evolução. Também faz algumas comparações entre os processos constitucionais e políticos brasileiros e outras experiências latino-americanas, avaliando se o Brasil iniciou ou não uma nova era de pensamento constitucional na América Latina.

Palavras-chave: Constituição; Estado de Direito; justiça; governança democrática; constitucionalismo liberal.

Como citar esse artigo/How to cite this article: ALVARADO, Arturo. The Brazilian Constitution of 1988: a comparative appraisal. Revista de Investigações Constitucionais, Curitiba, vol. 5, n. 3, p. 137-148, set./dez. 2018. DOI: 10.5380/rinc.v5i3.60966.

" Professor at the Center for Sociological Studies (Ciudad de México, México). Ph. D. in Social Sciences with major in Sociology at El Colegio de México (Ciudad de México, México). E-mail: alvarado@colmex.mx. 


\section{CONTENTS}

1. The Constitution and the current political situation of Brazil. 2. Some innovative features of Brazilian Constitution. 3. The Brazilian Constitution in the perspective of Latin America. 4. Concluding remarks. 5. References.

\section{THE CONSTITUTION AND THE CURRENT POLITICAL SITUATION OF BRAZIL}

This article examines the 1988 constitution of The Federative Republic of Brazil and its significance after 30 years of its implementation. Asserts some of its more advance social and political features and evaluates the current challenges to implement a democratic Rule of Law within the evolving constitutional framework. It also makes some comparisons between the Brazilian constitutional and political processes and other Latin American experiences. By doing so this paper tries to answer in which ways the Brazilian normative and democratic transformations either maintained or opened a new era of constitutionalism that departed from liberal conceptions of justice, when trying to solve historic and current quests for justice. ${ }^{1}$ To measure changes, the article revises the tensions produced in the economic and the social entitlements and the political features of the Carta Magna.

The 1988 constitution of Brazil was an advance in political and democratic agreements as well as an avant-garde document for Latin America economic, social and human rights. It is also the result of the struggle of pro-democratic social movements and the articulation of a political elite willing to exit the military rule with a new constitutional contract. It was also a successful exit from a period of military dictatorship that was the scourge of southern countries during the 1970's, and marked a shift in political contests for Brazil's political coalitions.

During the constitutional assembly, different political actors proposed social, economic and political arrangements that they expected to be stable, beyond the evolving political coalitions. They tried to establish stable, trustable and predictable governance provisions. Their design had some short and some long term consequences, among other things because they introduced a new set of fixed institutions they pretended to be stable and would/could last for long electoral cycles. During the first short term period political actors, like political parties, organizations and citizens should be able to learn and

\footnotetext{
${ }^{1}$ Some authors like to define the trend as new Latin American Constitutionalism, but I will argue that these ideas can be considered within the framework of a liberal conception of justice.
} 
integrate its rules and logics into their strategies. Other changes were long-term effects, chain like-transformations, been the conception of citizenship the deepest result. ${ }^{2}$

While the creators of this fixed Supreme Law attempted to avoid the temptation of different electoral coalitions to change the course and impose rules for the future, the dynamics of competition and the social mobilization impacted several of its features and shifted the navigation course. It can be said that the basic institutional design is strong and operative, and has survived governments with different ideologies, but I will like to propose that there are some governance tensions that explain the contemporary political crisis in the country. Some basic constitutional features need to be analyzed and estimate its strengths and capacity to guide the country outside the present stagnation, into a realistic future. To advance on these topics: the vicious cycle of violence, corruption and impunity; the partisan politics that produce conflicting and confronting majorities derives on the need for stronger independent judiciary, together with provisions to improve access to rights and justice and, overall, build a consensual Rule of Law, where all citizens and politicians will abide.

Other significant element is the combination of a presidential system articulated with a pluralist partisan congress and a federalist republic, which incorporates issues of republicanism and pluralism, but with different rules when compared to other cases like Mexico, Argentina or the United States. For instance, article 170 of the constitution establishes the mandate of reducing regional and social differences, and other articles mark strong promotion of deliberative political processes, ${ }^{3}$ together with a representative partisan system. The country has shown tensions between some features of democratic enhancement, like direct participation, in contrast with traditional partisan representation. As a bonus in the game there are signs of a more active judiciary.

In this sense, since 1988, Brazil embarked on a period of major transformations and I would like to highlight four substantive dimensions. First, the Carta Magna announced a new era of political, economic and social rights precisely at an important moment of economic changes at global level, and national policies must fit under the framework of the so-called Washington "Consensus". This is particularly important since Brazil's government will have to implement a package of reform policies promoted by Washington and several other institutions like IMF or IDB, in order to contain its hyper-inflation and government deficit. ${ }^{4}$ These issues have marked a sturdy redirection

\footnotetext{
${ }^{2}$ Some scholars argue that the constitution marked the foundation of a new state but that would mean that every constitutional assembly creates a new "Leviathan", something that does not happen in Latin America. AVRITZER, Leonardo; MARONA, Marjorie. Judicialização da política no Brasil: ver além do constitucionalismo liberal para ver melhor. Revista Brasileira de Ciência Política, Brasília, n. 15, p. 69-94, set./dez. 2014.

${ }^{3}$ SUNSTEIN, Cass. Beyond the Republican Revival. The Yale Law Journal, New Haven, vol. 97, 1988. p. 1540.

${ }^{4}$ Which included tax discipline and reform; redirection of public spending from subsidies; trade and foreign direct investment liberalization; privatization of public enterprises; deregulation and strengthening of private property rights. One constitutional provision previewed by the Fundamental Law happened in October 5, 1993
} 
for Brazilian government coalitions during the 1990's and were not achieved without strong fights, because it limited the provision of good and the access to economic and social welfare.

Second, like other countries in the region, Brazil experienced an increasing and unstoppable crisis of violence at multiple and interweaved levels, that was accompanied by a human rights crises. The country has an extremely high homicide violence rate together with organized crime, with unfair and arbitrary detentions of black populations, police lethality, massacres and violations of human rights in prisons. Its cities experienced a violent period of life, where criminal organizations controlled entire jails and territories, followed by military operations in states that trespassed governance and legal lines, forcing everybody to ask: who governs these regions? Today the military still have strong presence in various arenas, that some consider to be beyond the constitutional framework, and both the military and organized criminal bosses stall underneath the interstices of democratic power. All of this happens with a level of impunity that demonstrated the incapacity of the State to protect citizens' basic rights. But there are other deep infringements in the rights to health, education, and discrimination to major portions of vulnerable populations.

The third theme I would like to stress and is perhaps the more linked to constitutional features is the political and legal dynamics. Brazil has an electoral and partisan system that is the cause of confrontation and the current political crisis. It is a structure induced instability. Politics is the landscape of major conflicts and eroding political fights. These political confrontations are ingrained into the basic electoral laws and governance institutional provisions, and enduring hostility between the Executive and different political coalitions on the Congress. Its current profound crisis is partly the result of various rampant corruption scandals that recently lead to a political and judicial crisis because of the destitution of its president, the accusation against the current head of the Executive and the recent detention of Lula da Silva.

I would like to add that this is just the window dressing room of major crisis with potentially continental scale: the lava jato scandal, involving not only leaders of political coalitions but also major transnational capitalist corporations, like Oderbrecht, is now investigated even by offices from foreign governments. ${ }^{5}$ Brazilian politics are not nurtured by preference aggregation policies, but by corruption strategies and conspiration scandals, a monster that eats its own creatures, no matter the motivation; from

with an amendment that provide new guidelines to public policies with a focus on citizens. AVRITZER, Leonardo; MARONA, Marjorie. Judicialização da política no Brasil: ver além do constitucionalismo liberal para ver melhor. Revista Brasileira de Ciência Política, Brasília, n. 15, p. 69-94, set./dez. 2014. p. 80.

${ }^{5}$ This is the case of a Brazilian transnational enterprise, but also opens the issue of the increasing power of national and international corporations in state governance, and the limits that contemporary constitutions have for this cases. It is not clear how the government is protecting the rights of people against predatory practices of this corporations. 
Color de Mello impeachment in the 1990's, to the destitution of Dilma Rousseff and then the imprisonment of Luiz Inácio Lula da Silva, with current president Temer under attack, accused of corruption charges. All of this has depended on the majority of a congress that has provided Brazilians with enough evidence of negligence.

Together with the trends that have accompanied this corroding development of impune corruption is the increasing wave of violent crime and illegalities, which in certain cases has taken the form of internal confrontations between state and non-state armed actors, but in other forms it is a political confrontation among corrupt coalitions that seem to involve the cooptation or integration of both criminal bosses and the elite in one ruling coalition, a reconfiguration of the power coalitions of the State. ${ }^{6}$ The paradox is that most of these governments do not collapse, instead, they carry out regular electoral processes with enormous conflicts and illegitimate results, despite citizen's struggles.

The most dramatic consequence of this violence is that Latin American people have lived under a "State of Terror", spanning from its local forms of precarious gangs in neighborhoods, favelas, and barrios, to cities under the complete control of criminal organizations, such as the Primeiro Commando de la Capital in Sao Paulo. ${ }^{7}$

As a consequence of the three former dimensions that substantiate the abysmal distance between the written entitlements and the real every day deprivation of rights, the fourth must important feature is the lack of a Rule of Law. The task of creating a fair and lawful government was not the only challenge for the elite and the masses. For decades, several factors have impeded the accomplishment of this goal. Governments have shared a set of legal principles, institutions, processes, and regulations that are formally democratic, even though they score low in several governance indicators, like high inequality, rampant corruption widespread illegal activities at all levels, lack of transparency, un-controlled organized violence and impunity, limited freedom of the press, an absence of the monopoly of legitimate violence and incomplete territorial control of their states (limited sovereignty).

After stating these issues, we need to ask: Are these unintended consequences, incidental conditions of democratization? Are they indicators of a major shift in State

\footnotetext{
${ }^{6}$ The ruling elite plays power strategies and enjoys its involvement in corruptions scandals with such impunity that it has put the regime in a most dangerous situation. They survive with a complex formula in which legal authorities respond to illicit actors, producing incentives and threats that are accepted by governments. Elites still participate in elections and in forming governments. Meanwhile, some citizens also behave in an incongruent fashion: accepting clientelism and other illegitimate incentives to vote, even when their governments do not respond to them and fail to provide the benefit of public services. Elections partisan competition and distribution of power is carried out, but the results are not representative governments, but another type of autocratic government. See GARAY, Luis; DE LEÓN, Isaac; SALCEDO-ALBARÁN, Eduardo. Captura y Reconfiguración Cooptada del Estado en Guatemala, Colombia y México. Método, Bogotá, n. 64, p. 3- 45, ene. 2010.

${ }^{7}$ ADORNO, Sergio. Democracy in Progress in Contemporary Brazil: Corruption, Organized Crime, Violence and New Paths to the Rule of Law. International Journal of Criminology and Sociology, Ontario, vol. 2, p. 409425, oct. 2013.
} 
Governance beyond the constitutional framework? What is the part of the constitution in this outcome ${ }^{8}$ What has remained from the old regime and what has changed, that produces these outcomes?

In the last 30 years Brazil's population grew circa $50 \%$ and today $86 \%$ of Brazilians live in cities. Illiteracy has been reduced; education, sanitary, and general conditions improved; life expectancy and per-cápita income increased; but poverty and inequality indexes have been scarcely reduced, showing the limits of transforming structural opportunities. There are improvements, but not enough to say that problems are resolved. Regarding the governments, budgets have increased monumentally, but in spite of that people still are not able to receive the benefits of their policies and have not fair access to constitutional rights. The Brazilian economy is more market oriented and the current crisis shows the weakness of some achievements, especially because is vulnerable to political actions. Some generations of Brazilians that grew with the idea of entitlements, and the promising role of the state as major provider are living today in desolation. As mentioned before, one of the main paradoxes of Brazilian Constitution is that it was written at the end of a promising welfare state era, but there is a major downsizing of the public sector; the irresistible reduction of Brazilian public administration and its re-accommodation into a more fitted, but decadent government, less capable of providing all the services.

\section{SOME INNOVATIVE FEATURES OF BRAZILIAN CONSTITUTION}

I shall begin this section with the first article that establishes the clue concepts of citizenship, human dignity and political pluralism. The first idea has been one of the cardinal concepts of the development of a Human Rights framework in the region. Today must of the constitutions consider the concept of dignity as the basis of rights and entitlements. That proposition has reinforced the mandate that international relations are to be conducted with the prevalence of human rights (article $4^{\text {th }}$.); and can be complemented with the ideas of building a free, just and solidary society that guarantee national development, eradicate poverty, substandard living conditions and reduce social and regional inequalities (article $3^{\text {rd }}$. and others); also significant is the promotion of the well-being of all citizens, without prejudice as to origin, race, sex, or any other form of discrimination, such as the recognition of the indigenous peoples rights to their lands. This is a comprehensive framework of human rights that can be compatible with a liberal doctrine of justice.

Other innovative features of the Carta Magna were the establishment of urban policies as a constitutional matter, something that had not occurred in the region before

${ }^{8}$ I would like to mention that since its declaration, the Constitution has experienced 99 amendments and 6 special constitutional revisions. 
suggesting the social functions of the city in ensuring the well-being of its inhabitants. But it is necessary to address that other articles of the Constitution offer a different idea of the political contract that was forged at the constitutional assembly, in compliance with agreements from the ancient regime. For instance, Articles $142^{\text {th }}$ and $144^{\text {th }}$ offer a clear idea of the limits of any associational contract that eliminates the former regime. This has left open the probability of military interventions and has permitted the evolution of several questionable and "exceptional" punitive policies, like the interventions of military police corps in Favelas (Policía pacificadora programs), or the recent intervention of the federal forces in the State of Rio. Certain texts of the constitutions and its public policies have opened opportunities for what is called "states of exceptions" in Latin America. Mexico's federal courts for example, are facing cases related to the role of armed forces in public security.

\section{THE BRAZILIAN CONSTITUTION IN THE PERSPECTIVE OF LATIN AMERICA}

The constitutional movement of Brazil also marks a new wave of reforms in the subcontinent. First, because it was written with a different constitutional approach; second, it was more of a convention voted by both citizens and social movements that struggle against dictatorship, and a political and military elite willing to convene a democracy. Third, there was a different context contrary, for example, to the Chilean constitutional transition that had strong control of the military. So it can be said that Brazil started a wave of new constitutional ideas and ideologies, which were later unraveled in the Colombia reforms of 1991; and followed by Paraguay in 1992, Peru in 1993, Venezuela in 1999; Ecuador in 2008; Bolivia in 2009 and then Mexico in 2012. Mexico in contrast with several other nations of the subcontinent, took almost 25 years to achieve a human rights framework as the foundation of people's rights. This was not a new constitution but a major reform.

I would like to enhance several novelties of Brazil's constitution, and contrast them with new ideas, institutions and other improvements made later on by other national assemblies in the continent. It is necessary to address the question if this is a new trend of constitutionalism in Latin America (beyond old constitutionalist paradigms, either conservative or garantists); and/or an innovative sign of structural changes in contemporary governance.

It could be argued that this case started a new constitutionalist conception, like several scholars have proposed. ${ }^{9}$ But I have to state that there is not a single, coherent

\footnotetext{
${ }^{9}$ Negreto argues that Latin American countries started a wave of constitutional change since 1978. One of the new trend is a coexistence between party representation in a more pluralist setting, together with consensual-deliberative decision making procedures; other reforms foster concentration of power in the executive
} 
idea of a new constitutional design; every country arrived to the constitutional change from different routes and from different political formations (partisan and veto power actors, like the military). To be sure, Brazil and later on several countries established new rights, entitlements and constitutional figures. I can emphasize on the historical indigenous rights achievements, together with other minorities and collective rights; such as the fight for racial and gender equality, the multicultural identity of citizens and the plurinational states. ${ }^{10}$ Other important topic is the new juridical pluralism in Colombia and even in Mexico. According to Uprimni ${ }^{11}$ the common trends are transformative, egalitarian, participatory, and pluralist. Is important to assess that this is a result of citizens' struggles in the context of inequality and cultural heterogeneity.

But in the governance features the results are suboptimal. Still, I will like to propose that the majority of these ideas need to be discussed within the frame of a liberal conception of justice. There is a similar recognition of diversity, expansion, and protection of individual and collective rights in liberal conceptions of justice, as well within political liberalism.

And for sure access to justice has been one of the most active drivers of political and constitutional debates, whit no conclusive results today. There are also some features of constitutional revision that need to be taken into consideration like the new Supreme Court decisions, or the increasing presence of an Inter-American Court of Human Rights in issues of entitlements. But these are new trends that are going beyond Brazil's reforms.

We can discuss the innovative political decisions and policy design practices, like the direct participation. This mechanisms and other forms of collective decisions might be in confrontation with traditional representative partisan decisions, and the judicial review of the processes, but the case might still fit into a pluralistic idea of democratization.

Following Gargarella, the two critical variables to characterize these constitutional theories as different are: 1 ) how much the constitutions recognize and protect fundamental rights; and 2) how much space the constitutions grant to democratic participation in order to make collective decisions. ${ }^{12}$ In addition, Gargarella proposes that

branch (Like in Venezuela). According to him, constitutional choices are endogenous to the performance of preexisting constitutional structures and to the Partisan interests and relative power of reformers. According to him Latin America reflects the heterogeneous interests of the actors who had influence over institutional selection. NEGRETO, Gabriel. Shifting Constitutional Designs in Latin America: A Two-Level Explanation. Texas Law Review, Austin, vol. 89, 2011. p. 1777.

${ }^{10}$ AVRITZER, Leonardo; MARONA, Marjorie. Judicialização da política no Brasil: ver além do constitucionalismo liberal para ver melhor. Revista Brasileira de Ciência Política, Brasília, n. 15, p. 69-94, set./dez. 2014. p. 79-80. ${ }^{11}$ UPRIMNY, Rodrigo. The Recent Transformation of Constitutional Law in Latin America:Trends and Challenges. Texas Law Review, Austin, vol. 89, 2011. p. 1587, 1599.

${ }^{12}$ UPRIMNY, Rodrigo. The Recent Transformation of Constitutional Law in Latin America:Trends and Challenges. Texas Law Review, Austin, vol. 89, 2011. 
other new regional paradigm of constitutionalism is a great judicial independence such as Argentina. ${ }^{13}$

It is worth considering the new role of the judiciary system as a more active agent of protection and expansion of rights, and as a limit to political abuse by other actors. ${ }^{14}$ But this new active judiciary does not walk in one single direction. ${ }^{15}$ Avritzer perceives both directions in the new role of the judiciary in Brazil. But together with these innovations we can also notice some emerging practices from national executives in legislative and political arenas, that are justified and legitimized as interventions against the inefficiencies of representative democracies and have produced revolting conflicts. This can be the case of Venezuela, where the president confronted and challenged the limiting abilities of both legislative and judiciary systems, in the name of constituency. And there is the case of new trends in the Executives in Latin America that concentrate more power in security policies, giving the military a stronger role in state and internal security.

As a synthesis, I want to recover one issue highlighted before, which is a pending matter for all regional governments: building a Rule of Law. No constitutional reform has produced that result, and political elites that promoted the changes are still fighting for reforms; all of them can be integrated in the single idea of retain power. The systematic struggle for presidential reelection manifest that elites are running out of the limits of the Rule of Law.

It is also important to notice that constitutions are products of different historical, political and social mobilizations, but they all share the same purpose of building a more just society and a more fitted government. Their purpose is to make the constitutional rights more accessible for citizens, especially those in disadvantage. They might separate from liberal philosophies of justice, understood as fairness. It is in this case that they offer no options to the most striking contemporary problems of creating a fair world, were certain principles of justice will govern a modern social order. ${ }^{16}$

\footnotetext{
${ }^{13}$ GARGARELLA, Roberto. Recientes reformas constitucionales en América Latina: una primera aproximación. Desarrollo Económico, Buenos Aires, vol. 36, n. 144, jun./ mar. 2013. p. 977.

In the case of the judiciary, analyzes the 45th Amendment to the Brazilian Constitution, that enlarges the access to the justice in this country. RIBEIRO, Ludmila. The Constitutional Amendment $\mathbf{4 5}$ and the access to the justice. Revista Direito GV, São Paulo, vol. 4, n. 2, p. 465-491, jul./ dez. 2008.

${ }^{14}$ It is worth telling that the current political discussion puts stress on the competing roles of two different concepts of liberty and the role of the judiciary in it. Constitutions are limits to governing elites; they are not antidemocratic, but ensure fair procedures beyond electoral coalitions and the judicial review that emanates from the discretional interpretation of judges.

${ }^{15}$ For the Judicialization of politics see: AVRITZER, Leonardo; MARONA, Marjorie. Judicialização da política no Brasil: ver além do constitucionalismo liberal para ver melhor. Revista Brasileira de Ciência Política, Brasília, n. 15, p. 69-94, set./dez. 2014. p. 90.

${ }^{16}$ RAWLS, John. The law of peoples: with "The idea of public reason revisited". Massachusetts: Harvard University Press, 2001.
} 


\section{CONCLUDING REMARKS}

Sometime between the late 1980's and the beginning of this century, a great majority of Latin America's political regimes started to be elected with democratic methods; some of then went to a period of deep constitutional reforms, notwithstanding the fact that the construction of the Rule of Law was and still is a pending matter. Today, almost all of them promote a more active constitutionalism formerly fight corruption and created transparency organizations, but no one has achieved a minimum standard.

Although political liberties associated with democracy (i.e., suffrage of rights, association and freedom of speech) have been secured in many countries, the systematic violation of human rights by governments still poses a major challenge across the region. Moreover, several countries in the region continue to suffer from high levels of economic inequality, social exclusion, and discrimination along ethnic, racial, and gender lines.

This essay proposes that Brazilian constitution created important historical advances for its citizens and for other constitutions in the region. But on the negative side, the institutional provisions to implement them lacked capacity, political will and strength. There is an abysmal distance between formal entitlements and the absence of access to basic rights for the majority of population. Along with these deficits, the constitutional political machinery has encouraged the elite to behave in a devastating political fight, due to its own ambition, its incapacity and its involvement in illegal and illegitimate behavior. Most of it is the result of the electoral and political rules embedded in the system.

This article values the innovative propositions of rights and entitlements of the Carta Magna and examines four important dynamics that are driving the current political economic and even social crisis in the country. Some of them are connected to constitutional designs, other came as long term consequences of the implementation of this fundamental law. The first one is the contrasting capacity and response of the government to both the economic entitlements of Brazilians; the strong, deep condition of poverty and inequality, and the insufficient performance of the government policies. Even the appraised policies to combat poverty like Bolsa Familia, that some claimed was capable of changing structural dynamics, reduce poverty and increase an upward class mobility, looks weak in the midst of the recession. Besides, the corporate scandals that actually launched the current crisis are a signal of the size of corporate pressure on economics that hinders real growth and wealth creation and distribution.

The second profound problem of Brazil is the multidimensional violence that endangers basic rights; the dimensions run from high rates of homicidal aggressions, to criminal organizations controlling cities and putting people under a state of terror, corruption and impunity of large scale, to the disaffection of the basic rules of engagement 
in the political and juridical arenas. Criminal and illicit activities eroded the ability of States to govern democratically. The next two dimensions explored are the political features that underlie the dynamics of contentions (a confrontation that lead to the current crisis), and the consequent inexistence of a Rule of Law established as a promise in the Carta Magna but derogated by every day political practices.

More economic reforms are needed in order to guarantee better results for their constitutional promises, as well as a better system of cooperation that provides the necessary public goods to exit historic conditions of poverty, inequality and deprivation. The key state holders need to consent on the basic rules of the game. Latin America needs to address these problems in order to break the vicious cycle of violence, corruption and impunity of the eroding partisan politics that produce conflicting majorities. Political confrontations today are nourished by groups linked to political parties beyond citizens' interests. There is also need for a stronger independent judiciary system, that creates better access to rights, justice and overall a road to a consensual Rule of Law.

Democracy is more than a set of institutional rules that create governments. Is a social system that polices corruption, limits violence, protect its citizens to promote their legitimate involvement and curbs violations of the Rule of Law ${ }^{17}$

Finally, I argue that Brazil opened a new enlighted age of constitutional reforms and way of thinking. Whether or not this is a new school is still in discussion, but I argue that must of its "creations" can still be interpreted and explained within a liberal conception of justice and its associated political conception. Of course it can be said, and I will agree, that the "new era" has several innovative actions, new rights, a new conception of the person and a multidimensional-enriched idea of citizenship. But some of the institutional figures and rules established in constitutions incepted after 1988 are still for grabs. Again, several of its political arrangements have produced more institutional tensions and conflicts rather than solving the old disorder. Some of them are related to the direct participatory processes; others to a new role of the Executives and other to new functions of the judiciary, but none of them has been able to solve the puzzling issue of extremely pluralistic, fragmented and conflicting partisan electoral system.

\section{REFERENCES}

ACEMOGLU, Daron; ROBINSON, James; SANTOS, Rafael. The Monopoly of Violence: Evidence from Colombia. National Bureau of Economic Research, Massachusetts, vol. 11, p. 5- 44, Dec. 2009

\footnotetext{
${ }^{17}$ O'DONNELL, Guillermo. Polyarchies and the (Un)Rule of Law in Latin America. The Helen Kellogg Institute for International Studies, Chicago, sept. 1998. p. 1- 41; COX, Gary; NORTHON, Douglass; WEINGAST, Barry. The Violence Trap: A Political-Economic Approach to the Problems of Development. Available at: $<$ https:// papers.ssrn.com/sol3/papers.cfm?abstract_id=2370622>.
} 
ACEMOGLU, Daron; TICCHI, David; Vindigni, Andrea. Persistence of Civil Wars. Journal of the European Economic Association, Oxford, vol. 8, p. 664- 676, Apr./May. 2009.

ADORNO, Sergio. Democracy in Progress in Contemporary Brazil: Corruption, Organized Crime, Violence and New Paths to the Rule of Law. International Journal of Criminology and Sociology, Ontario, vol. 2, p. 409-425, Oct. 2013.

AVRITZER, Leonardo; MARONA, Marjorie. Judicialização da política no Brasil: ver além do constitucionalismo liberal para ver melhor. Revista Brasileira de Ciência Política, Brasília, n.15, p. 69-94, set./dez. 2014.

CÂMARA DOS DEPUTADOS. Constituição da república Federativa do Brasil, 1988. 35. ed. Brasil: Centro de Documentação e Informação, 2012.

COX, Gary; NORTHON, Douglass; WEINGAST, Barry. The Violence Trap: A Political-Economic Approach to the Problems of Development. Available at: <https://papers.ssrn.com/sol3/papers.cfm?abstract_id=2370622>.

GARAY, Luis; DE LEÓN, Isaac; SALCEDO-ALBARÁN, Eduardo. Captura y Reconfiguración Cooptada del Estado en Guatemala, Colombia y México. Método, Bogotá, n. 64, p. 3-45, ene. 2010.

GARGARELLA, Roberto. Recientes reformas constitucionales en América Latina: una primera aproximación. Desarrollo Económico, Buenos Aires, vol. 36, n. 144, p. 971- 990, jun./ mar. 2013.

NEGRETO, Gabriel. Shifting Constitutional Designs in Latin America: A Two-Level Explanation. Texas Law Review, Austin, vol. 89, p. 1777- 1779. 2011.

O'DONNELL, Guillermo. Polyarchies and the (Un)Rule of Law in Latin America. The Helen Kellogg Institute for International Studies, Chicago, p. 1- 41, sept. 1998.

RAWLS, John. The law of peoples: with "The idea of public reason revisited". Massachusetts: Harvard University Press, 2001.

RIBEIRO, Ludmila. The Constitutional Amendment $\mathbf{4 5}$ and the access to the justice. Revista Direito GV, São Paulo, vol. 4, n. 2, p. 465-491, jul./ dez. 2008

SUNSTEIN, Cass. Beyond the Republican Revival. The Yale Law Journal, New Haven, vol. 97, p. 1539- 1590, 1988.

UPRIMNY, Rodrigo. The Recent Transformation of Constitutional Law in Latin America: Trends and Challenges. Texas Law Review, Austin, vol. 89. p. 1586- 1609, 2011. 